\title{
FORMING THE STRATEGY OF INTEGRATED DEVELOPMENT OF TOURISM ENTERPRISES
}

\author{
Yuriy Kozak ${ }^{1}$, Tatyana Derkach ${ }^{2}$, Daria $\mathrm{Huz}^{3}$
}

\begin{abstract}
Considering the place and role of tourism in the life of society, in the European space, it has been proclaimed one of the priority directions for the development of national culture and economy. The development of the tourism sphere in the European space will contribute to the growth of the country's authority in the world market for tourist services, the strengthening of the country's economy, the filling of the state budget, the growth of the well-being of citizens, the preservation of the historical and cultural heritage, the enhancement of the spiritual potential of society. The purpose of the article is to substantiate the theoretical and methodological foundations of the formation of the strategy of integrated development of subjects of the tourism sphere in the conditions of transformational changes of the economy on the example of Ukraine. Methodology. Legislative and regulatory documents, periodicals, statistics, and Internet resources made up the information base of the study. General and special methods are applied in the work: monographic survey, generalization, systematization, economic and statistical analysis. This made it possible to investigate the current state of development of entities of the tourism industry and the possibility of forming a strategy for their integrated development, to provide organizational recommendations for the implementation of the strategy of integrated development of subjects of the tourism industry and the criteria for evaluating its effectiveness. Results. The components of strategies of integrated development of subjects of tourism sphere are considered, namely: the strategy of ensuring economic security; financial strategy; investment strategy; innovative strategy; information strategy. The factors that cause the need to create tourist clusters to ensure the sustainable development of subjects of the tourism sector are identified, such as: instability of the national economy; features of the tourism sphere; the structure of participants in the tourist market; peculiarities of activity of small business entities. Organizational recommendations for the creation of a cluster of subjects of tourism in the following areas: the type of integration structure, the number of participants, the consistency of interests of participants, the type of activity of participants, the distribution of responsibilities between participants. The scheme of implementation of the strategy of integrated development of subjects of tourist sphere is offered, which consists of the following stages: analysis of conditions of cluster formation, definition of purpose and tasks of the cluster, identification of potential and interested participants of the cluster, assessment of the level of consistency of interests of cluster participants, definition of rules of functioning of the cluster, development and implementation of the cluster strategy, cluster performance assessment and monitoring. Practical meaning. The introduction of these results in order to ensure sustainable economic development of the subjects of the tourism sector will contribute to the growth of the country's authority in the world market for tourist services, strengthening the country's economy, filling the state budget, increasing the well-being of citizens, preserving the historical and cultural heritage, enhancing the spiritual potential of society. Value/originality. The author's definition of sustainable economic development of the tourist industry entity, organizational principles of implementation of the strategy of integrated development of tourism industry subjects, methodical approaches to the evaluation of the strategy of integrated development of the tourism industry entities.
\end{abstract}

Key words: tourism, development, strategy, integration, sustainability.

JEL Classification: E20, E60, L12, L22

\footnotetext{
Corresponding author:

${ }^{1}$ Odessa National Economic University, Ukraine.

E-mail: yuriy777kozak@gmail.com

ORCID: https://orcid.org/0000-0002-5358-4420

${ }^{2}$ International Humanitarian University, Ukraine.

E-mail: rubinodessa@gmail.com

ORCID: https://orcid.org/0000-0003-1431-7300

${ }^{3}$ Odessa I. I. Mechnikov National University, Ukraine.

E-mail: daryaguz26@gmail.com

ORCID: https://orcid.org/0000-0002-6429-2191
} 


\section{Introduction}

Considering the place and role of tourism in the life of society, in the European space, it has been proclaimed one of the priority directions for the development of national culture and economy. The development of the tourism sphere in the European space will contribute to the growth of the country's authority in the world market of tourist services, the strengthening of the country's economy, the filling of the state budget, the growth of the well-being of citizens, the preservation of the historical and cultural heritage, the enhancement of the spiritual potential of society.

Tourism in the national macro-environment is currently functioning in the conditions of fierce global competition. Being an important component of the economy of our country as a factor that not only attracts most branches of the domestic economy to the development of tourism product but also stimulates their development, the tourism sector requires a thorough scientific and methodological research, including analysis of the current state of development, solving various problems of state regulation, forecasting, and prevention of potential risks and threats. The current state of tourism in Ukraine requires immediate improvement of state tourism policy mechanisms. Considering the experience of foreign countries, it can be stated that the dynamic development of the tourism sphere depends on the perception at the state level of the importance of tourism and the levers of state support used. According to the recommendations of the World Tourism Organization, the current state of tourism development requires state support first and then the private sector. Promoting the development of the tourism sector should be made taking into account its place in the economy of the country.

Research into the tourism sector and external prerequisites for the formation of a strategy for ensuring sustainable economic development of tourism industry entities has shown that in today's economic environment for many, the main problem is survival and sustainable development. An indispensable condition for the sustainable economic development of the tourism industry is the implementation of such management procedures, which are based on restructuring strategies. The kind of strategy is an integration strategy that ensures the development of each member of such an association. By working with another company, redistribution of efforts to counter various risks is possible. Thus, improvement of qualitative indicators of activity of the separate merging enterprise leads in this case to its development.

Among the entities in the tourism sector, small businesses are predominantly the most financially vulnerable and vulnerable to destructive change in an unstable economy. Thus, their development is hindered by the following factors: chronic lack of financial resources, hypersensitivity to economic fluctuations and political situation, high degree of dependence on the system of support of small business, considerable dependence on individual large customers, weak segmentation of own market share and insufficient strong position, it is at high risk and prone to bankruptcy. You can prevent the negative impact of these factors by applying a suitable integrated development strategy. This actualizes theoretical and applied research in this field.

\section{Theoretical foundations of the strategy of integrated development of tourism entities}

The Sustainable Economic Development Strategy is an integrated tourism development strategy that is implemented through the integration of tourism entities into a cluster.

The purpose of the Integrated Development Strategy is the sustainable economic development of the tourism industry.

The sustainable economic development of the tourist industry is the invariance of economic development indicators in successive periods of time, which contributes to improving the level of economic security, improving financial and information support, improving the efficiency of the innovation and investment policy of the tourism industry.

The main objective of the integrated tourism development entity's strategy is to identify priority areas for improving the entity's performance in order to improve the quality of their performance and counteract the environmental risks.

The process of formulating a strategy for sustainable economicdevelopmentrequiresadequatemethodological support, which allows an objective assessment of the consistent adaptation and harmonious development of the tourism industry subjects during integration. Therefore, it must meet the following requirements:

- such an alternative variant of the development strategy is formed, which provides the most complete solution of the set tasks, the minimum term for its execution, and the minimum possible total expenses for its implementation;

- the tasks should be specified in the context of the formation of the necessary conditions for the implementation of the development strategy, and the priority should be those that ensure the rational use of all available resources and reserves;

- it is advisable to foresee meaningful qualitative consequences of the strategy implementation and from the possible alternatives to choose the one that provides the maximum efficiency of the implemented measures (New Corporate Strategy, 1999).

As a result of consideration of the main tools for ensuring the sustainable economic development of the tourist industry, the need to ensure economic security as the most urgent tool in the uncertainty of the environment is highlighted. After all, the main objective 


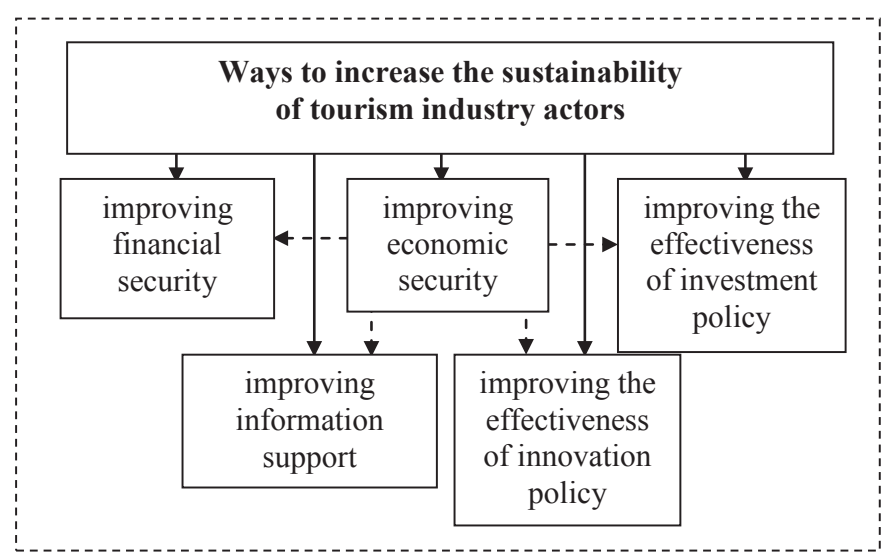

Figure 1. Ways to increase the sustainability of tourism industry actors

of the economic security of business entities is to counteract risks that adversely affect the sustainability of economic development.

Given the above, we can distinguish priority ways to increase the sustainability of the development of subjects of the tourism industry, such as the following (Figure 1): increasing the level of economic security; improving information support; improving financial security; improving the effectiveness of innovation policy; improving the effectiveness of investment policy.

In the process of forming an integrated development strategy, it is necessary to define its functional components.

Considering that the entity's functional strategies determine the main directions of its development and reflect the ways of achieving its goals, we consider the components of integrated development strategies (Table 1).

The next steps in the development of a strategy for the integrated development of the tourism industry are to define the mission, purpose, and objectives.
The process of formulating the mission of a tourist entity is very complex and responsible, and it must be well planned. After all, the mission must clearly describe the destination of the tourist entity and is established over a long period of time.

The purpose tree is built from top to bottom, from general goals to individual, more detailed goals. Yes, the achievement of the main goal is ensured by the realization of the lower-level goals. In turn, each of these goals can be divided into the next, lower-level goals. One of the basic principles of constructing a goal tree is the following: each goal of a given level must be represented as next-level goals in such a way that their totality fully defines the concept of the original goal.

The study of the features of the tourism sphere development makes it possible to build a tree of goals (Figure 2). Objective analysis and modelling methods are associated with decomposition, synthesis, and evaluation procedures.

Table 1

Functional components of integrated tourism development strategies

\begin{tabular}{|c|c|}
\hline Name & Characteristic \\
\hline $\begin{array}{l}\text { Economic security } \\
\text { strategy }\end{array}$ & $\begin{array}{l}\text { - protection of legal rights and interests; } \\
\text { - monitoring of the state of the environment; } \\
\text { - identification of potential threats to the activity and development of preventive measures to prevent or reduce risks; } \\
\text { - protection of confidential information concerning all parties of activity. }\end{array}$ \\
\hline Financial strategy & $\begin{array}{l}\text { - effective financial planning; } \\
\text { - regulation of the movement of financial resources; } \\
\text { - identification of sources of financing of activity; } \\
\text { - coordination of financial units. }\end{array}$ \\
\hline Investment strategy & $\begin{array}{l}\text { - ensuring the optimal structure of investment resources; } \\
\text { - ensuring minimization of costs of formation of investment resources; } \\
\text { - ensuring a high efficiency of the use of investment resources. }\end{array}$ \\
\hline Innovative strategy & $\begin{array}{l}\text { - improving the level of customer service; } \\
\text { - improving the quality and effectiveness of product advertising; } \\
\text { - application of innovative pricing methods to attract new customers; } \\
\text { - increase in production volumes of innovative products; } \\
\text { - introduction of the system of training and advanced training of employees. }\end{array}$ \\
\hline Information strategy & $\begin{array}{l}\text { - creating a system for collecting, processing, systematizing, and organizing information; } \\
\text { - formation of a complex information system; } \\
\text { - monitoring of information risks. }\end{array}$ \\
\hline
\end{tabular}




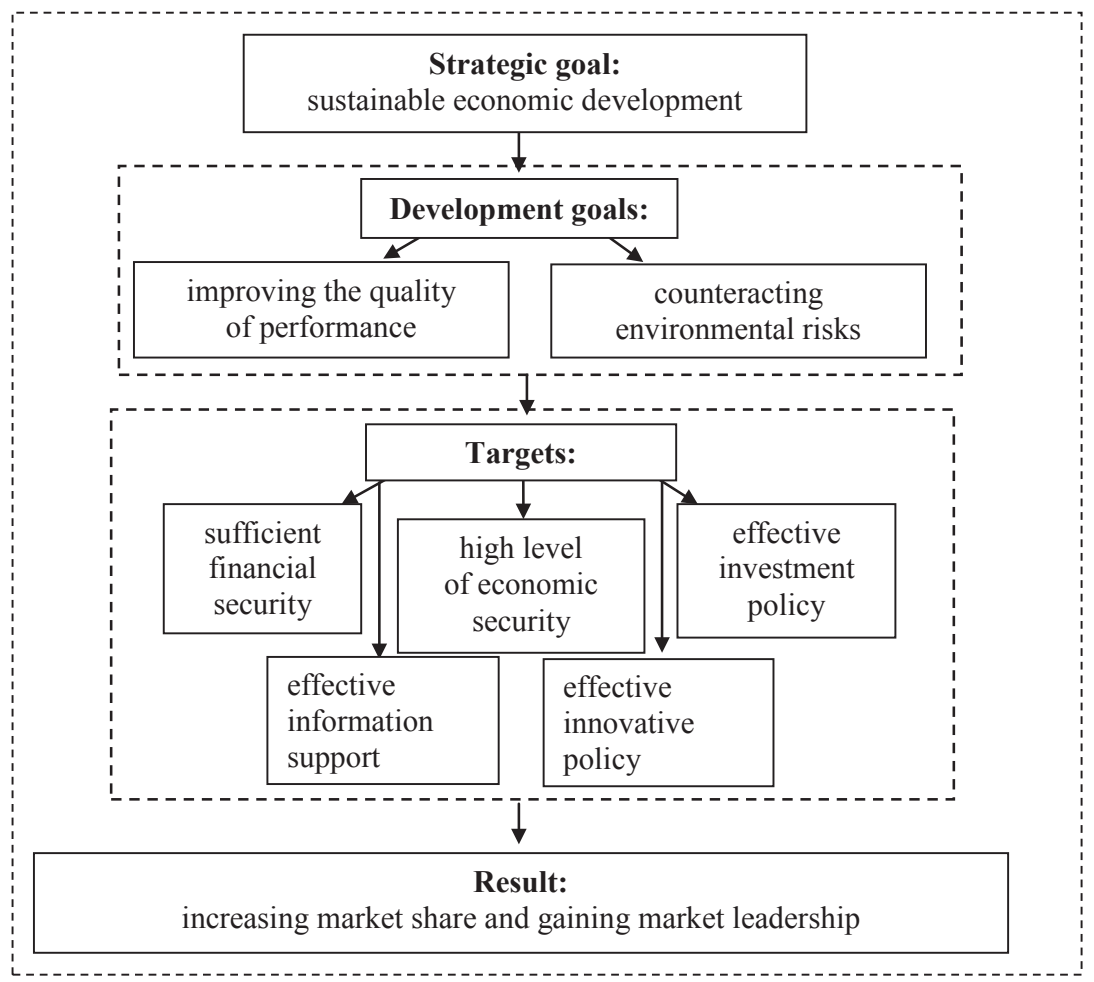

Figure 2. Destination tree of the tourism industry

The next steps in the development of an integrated development strategy for the tourism industry are to generate alternative development strategies and to select the most optimal development strategy.

Integrated development strategy is based on the integration of entities, through which they interact and redistribute efforts to address the diverse risks of the environment.

Thus, it is advisable to formulate alternative development strategies depending on the nature of the integration that underlies the integrated development strategy. The criteria for formulating alternative development strategies are the types of entities in the tourism industry that are united.

As a result of the conducted research on the specifics of the activity of small business entities and the features of tourism development, it is advisable to identify two alternative strategies of integrated development of tourism entities, namely:

- integration of small entities of the tourism industry with a large entity-leader;

- the integration of small entities of the tourism industry with each other.

Considering that the strategy of the integrated development of the subjects of the tourism industry is based on reconciling the interests of small business entities and uniting efforts in order to ensure their sustainable economic development, it is from this point of view that we must choose the most optimal development strategy from the existing alternative ones.

Let us analyse the alternative strategy of "Combining small business entities with a large subject leader" (Table 2).

Let us analyse the alternative strategy of "Integration of small business entities with each other" (Table 3 ).

Table 2

Characteristic of the alternative strategy of "Combining small business entities with a large entity leader"

\begin{tabular}{|c|c|}
\hline Adva & Disadv \\
\hline $\begin{array}{l}\text { Small business entities have access to the resources they need and } \\
\text { are able to use them effectively. } \\
\text { Receiving long-term small business entities. }\end{array}$ & $\begin{array}{l}\text { Possibility of loss of independence for small business entities. } \\
\text { The interests of small business entities are not fully taken into account. } \\
\text { Ability to absorb small business entities. }\end{array}$ \\
\hline
\end{tabular}

Table 3

Characteristic of the alternative strategy of "Integration of small business entities with each other"

\begin{tabular}{|l|l|}
\hline \multicolumn{1}{|c|}{ Advantages } & \multicolumn{1}{|c|}{ Disadvantages } \\
\hline $\begin{array}{l}\text { Small business entities are equal partners. } \\
\text { Consistency of interests of small business entities in joint activity. } \\
\text { Independence and flexibility of small business entities. }\end{array}$ & $\begin{array}{l}\text { Limited resources of small business entities. } \\
\text { The complexity of selecting homogeneous small business entities. }\end{array}$ \\
\hline
\end{tabular}


Through a survey of expert groups from tourism entities that are interested in joining forces to ensure their sustainable economic development, it is established that an alternative strategy of "Integration of small business entities with each other" is effective.

An effective strategy for integrated tourism development is to bring small businesses together. As a result of such an association, the group of its members appears homogeneous and equal due to the same characteristics as: current potential; development needs; strengths and weaknesses of the activity; threats to activity; possibility of exchange of benefits; joining forces to counter threats.

The sustainable economic development of the tourism industry is possible thanks to the creation of a tourist cluster.

Consider the prerequisites for creating a tourism cluster to ensure the sustainable development of tourism industry entities.

1. Instability of the national economy. Modern market relations are characterized by the volatility and uncertainty of the external environment of economic entities, the continuous emergence of new trends in the development of the economy and society, the acceleration of scientific and technological progress.

P. Kotler considers the term "turbulence" in his work Chaotics: The Business of Managing and Marketing in the Age of Turbulence. First of all, turbulence is defined as unpredictable and rapid changes in the internal and external environments of an entity that affect its activities. The world is becoming more interconnected, interdependent, and its "globalization" is accelerating (Chaotics: The Business of Managing and Marketing in the Age of Turbulence, 2009).

2. Features of the tourist sphere. The tourism sphere has a number of peculiar features only, which derive from the specific properties of services provided by the participants of the tourist market. The basic features of tourism as an object of management include the following:

- ambiguity and complexity in the measurement of goals: due to the fact that the tourism market participants do not have measurable goals, their performance and success cannot be objectively evaluated, that is, the probabilistic nature of the processes taking place in the tourism industry;

- a significant influence on the activity of the participants of the tourist market by the "interested clientele": each participant functions in the environment of different stakeholders and clients and, even within individual interest groups, have their own interests;

- the specificity of tourist services: it is related to the specificity of tourism demand. Demand for tourist services is not uniform for reasons such as: insensitivity and insecurity of the tourist product; diversity of consumers of tourist services, which leads to the fact that each type of tourists corresponds to a certain type of tourist market;
- the comprehensiveness of tourist services: this is all that the tourist takes into account or what he/she uses during the trip (when changing his/her place of stay and when staying at the destination of his/her trip). It follows that the tourist service is composed for the tourist from the whole complex of both tangible and intangible services, which is a specific tourism product. These individual tourist services complement the main; - creation of a tourist package with the participation of many enterprises, each of which has its own working methods, specific needs, and different commercial goals;

- dependence of the tourist service on such variables as time and space;

- external factors of force majeure have a significant influence on the quality of tourist services (Economy and Organization of Tourism and Hotel Business, 2007).

3. Structure of participants in the tourist market. In the process of developing and marketing a tourism product, business entities from different sectors of the economy that are pursuing their own interests are involved. In view of this fact, it is necessary to balance the interests of economic entities with the interests of environmental entities. The interests of the subjects of the tourism industry are very diverse, each of them is characterized by a set only of its own interests, which in a certain way are related to each other, have a different status, belonging to different entities. The interests of the tourist market participants are not only diverse but also extremely mobile, which is caused, on the one hand, by the continuous development of the tourist entity itself, and on the other, by constant changes in the external environment. However, despite the diversity and mobility of the interests of business entities, it is possible to distinguish priority interest that is characteristic of each participant of the tourist market ensuring sustainable economic development.

4. Features of activity of small business entities. In the domestic tourism sphere, small businesses predominate among a large number of economic entities. It is well known that there are a number of disadvantages in the activities of small business entities in the context of environmental variability. The main ones include the following: low financial support for the activity, sensitivity to the negative impact of environmental factors, a small share of the market in sales volume, fierce competition from the side of large entities in the industry. As a consequence, only a few are engaged in tour operator activity in the classical sense of the word. Others act mainly as intermediaries of foreign operators, adding some of their services to their tourism product. This situation can only be overcome by the emergence of powerful companies with significant working capital in the domestic tourism sector, as well as by the associations of tourism entities. 


\section{Form of implementation of the strategy of integrated development of tourism sphere actors}

The next step in the formation of the strategy for integrated development of the tourism industry is planning the implementation of the strategy.

The tourism sector is an inter-sectoral complex of business structures for the production and sale of the tourism product. It covers the activities ofallentities in the tourism business and third-party organizations involved in the implementation of the tour program and is an integrated system of industries and activities, combined by a common purpose. Thus, the implementation of the strategy of integrated development of subjects of tourism in the conditions of the economic and political instability of the country should be carried out taking into account the peculiarities of the complex structure of participants in the tourist market, and as a consequence of the lack of coordination of their activities.

The implementation of the strategy of integrated development of the subjects of tourism should be based on: first, properly organized and coordinated activities; secondly, a comprehensive approach to the study of various processes and phenomena, as well as factors and characteristics.

The main task of implementing an integrated development strategy is to create the necessary conditions for the successful implementation of the strategy.

Creating a cluster of tourism industry entities to increase the economic security of small business entities as a key tool for ensuring the sustainable economic development of tourism industry entities will help: increase the resilience of small business entities to the negative impact of environmental risks; ensuring the investment attractiveness of small business entities; increase of financial support for the activity of small business entities; innovative support for the activity of small business entities; improving the marketing policy of small business entities; increasing market share in terms of sales; improving the competitiveness of small business entities, etc.

In Figure 3, the interconnection of the cluster form of organization of cooperation with ensuring sustainable

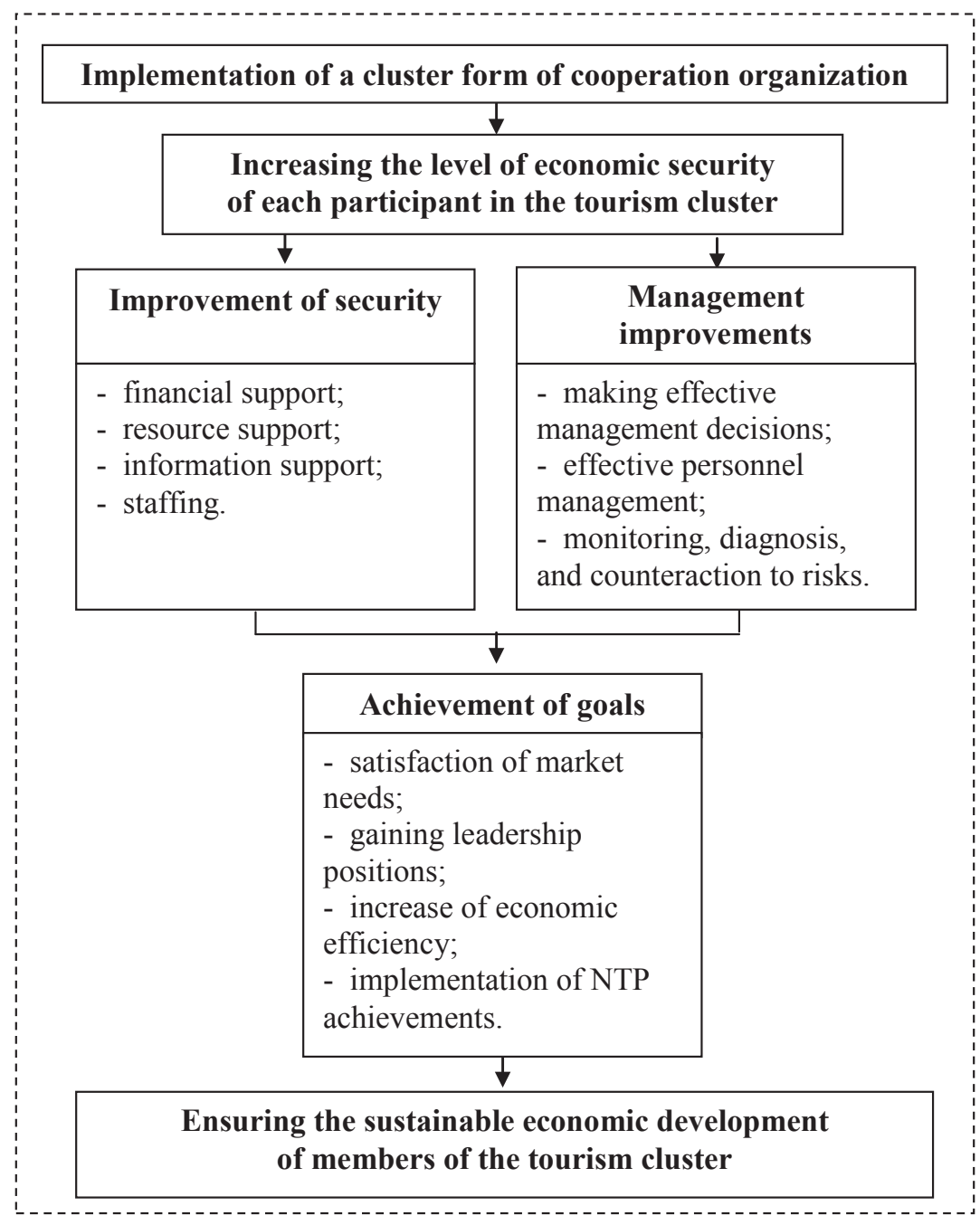

Figure 3. The interconnection of the cluster form of cooperation organization for sustainable economic development 
economic development of subjects of tourism sphere is depicted.

Solutions to the lack of coordination of activities of all participants in the tourism market are possible through the formation of an integrated development strategy through the implementation of sectoral integration and partnerships, which would take into account the interests of all participants in the tourism market.
After exploring the prerequisites for forming an integrated development strategy by creating a tourism cluster of small business entities, you can make the following recommendations for organizational directions (Table 4).

Consider the scheme of implementation of the strategy of integrated development of tourism entities (Figure 4).

Table 4

Organizational recommendations for the creation of a cluster of entities in the tourism industry

\begin{tabular}{|c|l|}
\hline Organizational direction & \multicolumn{1}{c|}{ Recommendations } \\
\hline Type of integration structure & $\begin{array}{l}\text { The cluster should be based on a horizontal integration structure, characterized by a broad market impact } \\
\text { and pricing flexibility. }\end{array}$ \\
\hline $\begin{array}{c}\text { Consistency of interests } \\
\text { of participants }\end{array}$ & $\begin{array}{l}\text { Combining businesses with many participants will work poorly. Since establishing democratic governance } \\
\text { principles and coordinating the activities of a cluster with a large number of participants is challenging. } \\
\text { According to the author, the cluster should consist of no more than five entities, which will ensure its } \\
\text { effectiveness. }\end{array}$ \\
\hline $\begin{array}{c}\text { Type of activity of participants } \\
\text { and subordination of the interests of all its participants. Businesses that have the same problems should try } \\
\text { to solve them as effectively as possible through joint efforts. Consistency of participants' interests is the } \\
\text { most important motivation and the main condition for their effective interaction. }\end{array}$ \\
\hline $\begin{array}{l}\text { Distribution of responsibilities } \\
\text { integration of small business entities with each other. As a result of the study of the peculiarities of the } \\
\text { development of the tourism sphere, the author has established that it is tourism agents that are mostly } \\
\text { small business entities. Thus, it is important to create a cluster that will include travel agents, as the largest } \\
\text { participants in the tourism market. }\end{array}$ \\
\hline $\begin{array}{l}\text { Topical is to create a cluster comprising travel agents as the largest participants in the tourism market. This } \\
\text { approach will ensure equal participation of participants in the joint activity and an equal contribution to } \\
\text { the end result. }\end{array}$ \\
\hline
\end{tabular}

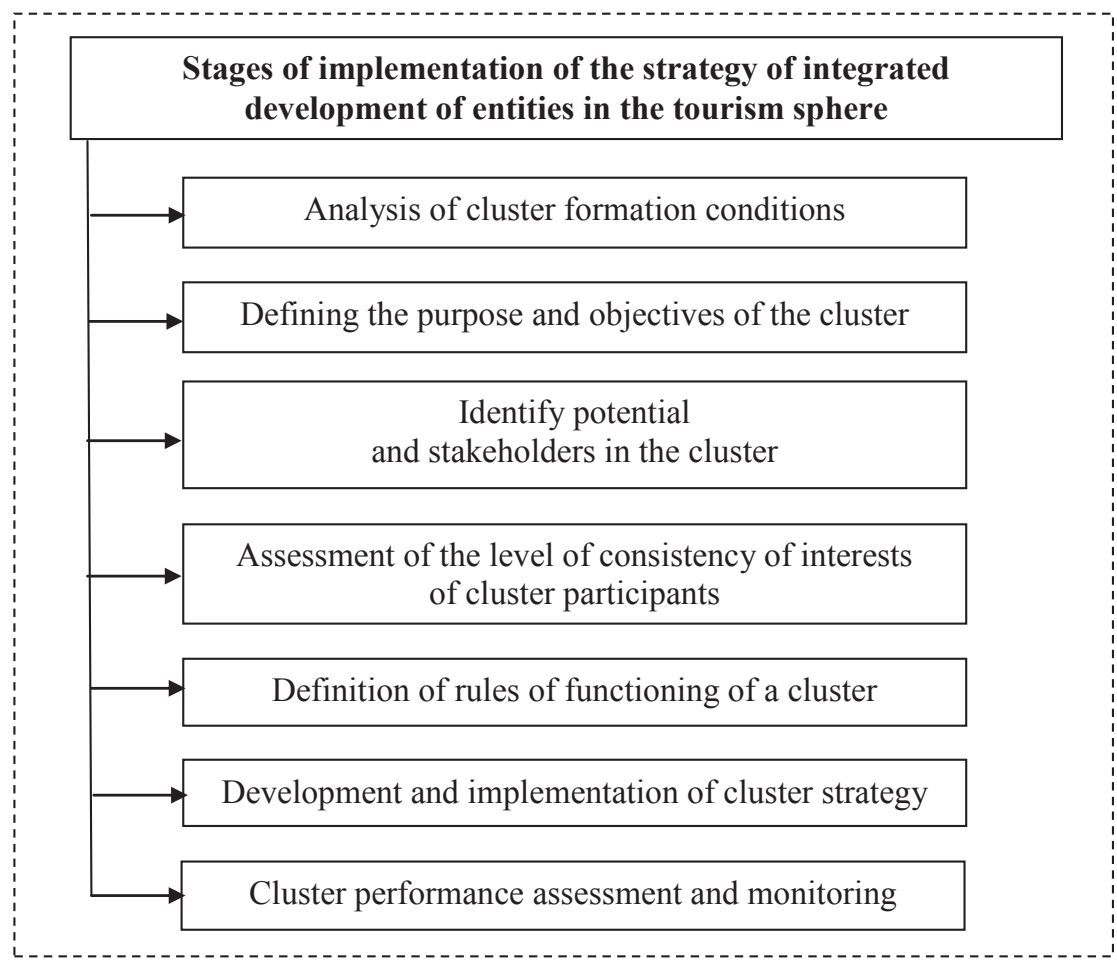

Figure 4. Stages of implementation of the strategy of integrated development of tourism sphere actors 
Analysis of conditions of cluster formation involves the following measures: analysis of industry development features; SWOT analysis of the region; analysis of socio-economic indicators of the region; study of the priorities of development of the region; analysis of the innovative activity of the region; definition of perspective directions, etc.

Properly defining the purpose and tasks of the cluster influences the whole activity of the cluster and determines its effectiveness. The purpose of the cluster is the end goal, the end result, to which the functioning of the cluster is directed.

The purpose of the cluster of entities in the tourism industry is to ensure the sustainable economic development of all members of the association.

The main tasks of the cluster include the following:

- ensuring sufficient financing for the activity;

- increasing the level of economic security;

- ensuring an effective investment policy;

- improving information support;

- ensuring an effective innovation policy.

The identification of potential and interested cluster participants involves the following activities:

- conducting an information campaign among potential participants and stakeholders in cluster formation;

- organizing large open meetings to present the principles of the cluster, to identify their capabilities and benefits.

The step of defining the rules of the cluster operation is as follows:

1. Development of the organizational structure of cluster management: the creation of the Coordination Centre; approval of the Charter; holding a constituent assembly, etc.

2. Formation of norms and rules of interaction of cluster participants: organization of representative offices of enterprises; creation of forms and methods of communication of participants; defining the principles of work in the cluster; planning and preparation of economic activities, etc.

Developing and implementing a cluster strategy involves: analysing common problems and opportunities; approval of the cluster work plan; forming and implementing an optimal strategy.

The cluster performance assessment covers the analysis of the performance targets and the development of proposals for adjusting the cluster activities.

The main condition for the effective organization of a cluster of entities in the tourism industry is the homogeneity of the group of participants who unite. Since the author considers small enterprises, which in turn are characterized by specific shortcomings in the activity, as a consequence, there is a need for a concerted consideration of their interests.

A homogeneous group of cluster participants is a group of actors with homogeneous priority economic interests who join forces to ensure that they are implemented as efficiently as possible and to ensure sustainable economic development.

Since a homogeneous group of cluster members have homogeneous economic interests, let us consider what should be understood by the economic interests of the tourism industry.

The economic interest is to achieve a satisfactory result in the process of economic relations of economic entities.

The subjects of economic interests are individuals, families, households, collectives, groups of people, the state, and society as a whole.

The object is the result of social production (product, service, etc.) that addresses the need for which specific relationships between people are formed (Economic Interests: Theory and Methodology of Research, 2003).

The study of the peculiarities of the activity of the small business in the tourism sphere has allowed establishing their main priority interests: improvement of quality indicators of activity; ensuring effective counteraction to environmental risks.

The realization of the stated interests of the subjects of the tourism industry will contribute to their sustainable economic development and increase of market share.

The organization of a cluster of subjects of the tourism industry with homogeneous priority interests should be based on their maximum coherence in order to motivate the subjects to interact. It is this aspect that will help to improve the organization of the cluster of subjects of the tourism industry.

Consistency of economic interests of cluster participants is the average value of mutual motivation for cooperation between two or more entities in order to ensure sustainable economic and economic development. Mutual motivation is seen as the level of motivation on one side and the other.

\section{Evaluation of the implementation of integrated development strategy of the tourism sphere entities}

On the first stage of the evaluation of the strategy for integrated development of the tourism industry, several groups of evaluation criteria need to be identified. In this case, given the definition of sustainable economic development of the tourist industry, it is advisable to define two groups of criteria for evaluating the strategy, namely:

1. The first group - qualitative changes in the activity of the subject of tourism sphere.

2 . The second group - counteracting the risks of the environment.

On the second stage of the evaluation of the strategy of integrated development of the tourism industry entities, it is necessary to determine the evaluation criteria in each group.

The first group should include such a criterion as the economic efficiency of the activity. 
The second group should be considered as a criterion for resilience to financial and commercial risks.

By area of origin, economic risks are divided into: financial, industrial, demographic, commercial, geopolitical, environmental, socio-political, administrative, and legislative.

Among these economic risks, financial and commercial risks should be considered. After all, as a result of the impact of financial risks on the activity of the tourist industry, the state of its financial stability is reduced and then, as a consequence, its level of solvency. Among the commercial risks, the most urgent and dangerous is the negative impact of fierce competition.

Given that small businesses are characterized by low levels of financial security and stiff competition from large entities, financial and commercial risks pose the greatest threat to the sustainable development of small businesses. Therefore, these types of risk are the most significant and will be considered in the future in the form of a decrease in financial stability and negative competition.

The goals of small business entities are different from those of big business entities, the most common and relevant ones being to increase the level of financial support for their business and to survive in the market in a highly competitive environment. Therefore, in formulating a strategy for the sustainable economic development of small business entities, it is necessary to use an approach that will take into account the peculiarities of such entities in the current economy.

On the third stage of evaluation of the strategy of integrated development of tourism sphere entities, it is necessary to evaluate the indicators according to the chosen criteria (Table 5).

To make a conclusion about the level of performance of a tourist entity, the profit must be compared with the expenses incurred. The effectiveness of the activity is analysed by the following indicators: profit, rate of return, profitability, as well as indicators of the use of labour resources (labour productivity), fixed assets (capital efficiency, capital intensity), material resources (material intensity, material efficiency), etc.

Profitability indicators are the relative characteristics of the financial performance and performance of a tourist entity. Profitability research is an important area of financial diagnostics. The research results provide answers to many questions related to financial and management decisions that underlie the competitiveness of the tourism industry.
The level of profitability as a whole characterizes the efficiency of only consumed production resources and does not reflect the efficiency of the use of all the upfront costs accumulated in the form of fixed and current assets used. Therefore, to determine the efficiency of the use of productive funds calculate the rate of return (Enterprise Economics, 2006).

Profit is an important indicator of the effective activity of a tourist entity. However, the absolute size of the profit does not indicate the level of efficiency, quality of work of the business entity. Therefore, in order to accurately determine the level of economic activity of a tourist entity, they use a relative rate of return, expressed as a percentage, called the rate of return. The rate of return reveals the relationship between the size of capital, the cost of production, price and mass of profit. From this relationship, we can conclude that maximizing profit depends on both the rate of return and the capital advanced.

The condition and guarantee of the survival and development of any tourist entity is its financial stability. Financial sustainability provides an opportunity to respond in time to unexpected changes in the market environment. Financial autonomy is one of the most important factors for financial sustainability. It is equal to the ratio of the company's equity to all financial resources.

An indicator of the potential benefits of a tourism industry entity is the market share it owns. Increasing market share is the primary goal of most tourism entities. According to this indicator, it is possible to assess the level of competitiveness of the tourist industry entity in terms of its market potential. The market share of the tourist industry entity reflects the most important results of the competition, captures the degree of its dominance in the market, its ability to influence the structure and volumes of supply and demand, prices and dynamics of the market as a whole.

In Table 6, a description of the criteria evaluation indicators is presented.

Given that travel agents are predominant in the national tourism market, it is advisable to analyse their integrated development strategy. As such, these tourism industry entities are overwhelmingly small business entities and are largely exposed to the destabilizing factors of the environment. This is due to the fact that travel agencies, in comparison

Table 5

Indicators of evaluation of development criteria

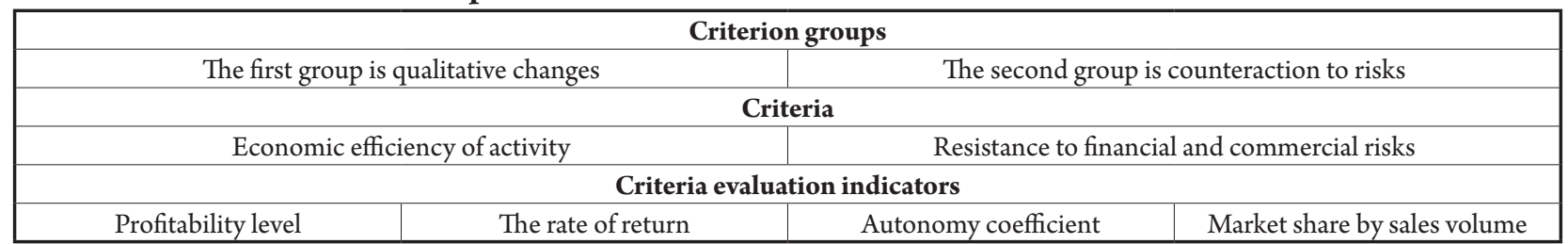


Table 6

Characteristics of criteria evaluation indicators

\begin{tabular}{|c|c|c|}
\hline Indicator & Calculation formula & Characteristic \\
\hline \multicolumn{3}{|c|}{ The first group is qualitative changes } \\
\hline Profitability level & $\mathrm{P}=\left(\mathrm{R}^{*} 100\right) / \mathrm{B}$ & Describes the efficiency of the consumed production resources. \\
\hline The rate of return & $\mathrm{Rr}=\left(\mathrm{R}^{*} 100\right) /(\mathrm{Pf})$ & Describes the efficiency of use of all production funds. \\
\hline \multicolumn{3}{|c|}{ The second group is counteraction to risks } \\
\hline Autonomy coefficient & Ac $=$ Equity $/$ Balance Sheet Currency & $\begin{array}{l}\text { Characterizes the share of own funds invested by the owners of } \\
\text { the enterprise in the total value of the property. The rate is } 0.5-0.8 \text {. }\end{array}$ \\
\hline $\begin{array}{l}\text { Market share of enterprises } \\
\text { by sales volume }\end{array}$ & $\begin{array}{l}\text { Ms }=\text { Number of goods sold / } \\
\text { Total sales of goods in the base market }\end{array}$ & $\begin{array}{l}\text { The share of goods of the enterprise in the total capacity } \\
\text { of this market. }\end{array}$ \\
\hline
\end{tabular}

with other participants in the tourist market, possess small financial, logistic, and human resources and also occupy a minimal market share.

In order to select the same entities of the tourism industry, the following characteristic features of their selection are proposed: number of employees; annual income; pricing policy; types of services.

On the fourth stage of evaluating the strategy of integrated development of the tourism industry entities, it is necessary to determine the integral indicators for each group of criteria: qualitative changes and counteraction to risks.

It is advisable to determine the level of evaluation of the strategy of integrated development of tourism entities based on the calculation of the overall indicator by criteria such as the efficiency of operations and resistance to financial and commercial risks.

$i_{c 1}=\sqrt{P \cdot H_{n}}$

$i_{c 1}-$ integral indicator of efficiency of activity of the subject of tourist sphere;

$P$ - standardized level of profitability of the tourist industry subject;

$H_{n}$ - standardized rate of return of the tourist entity;

$i_{c 2}=\sqrt{K_{a} \cdot \Psi_{p}}$

$i_{c 2}-$ an integral indicator of resilience to financial and commercial risks;

$K_{a}$ - standardized coefficient of autonomy of the tourist entity;

$\Psi_{p}$ - standardized market share of the tourism industry entity by sales volume.

$$
I_{\text {заг. }}=\sqrt{i_{c 1} \cdot i_{c 2}}
$$

$I_{\text {заг. }}$ - overall indicator of the tourism development entity's integrated development strategy.
Depending on the level of evaluation of the integrated development strategy, it is advisable to divide the tourism industry into three groups: high, medium, and low (Table 7).

Given the volatile development of the national economy of the country as a whole, as well as the existence of fierce competition in the tourism market, tourism industry actors should strive to join forces with other tourism industry actors in order to strengthen their position in the industry. An example of such an amalgamation is the cluster of entities in the tourism industry. Cluster members receive the following benefits in activities such as: redistribution of environmental risks; increase of financial support of activity; increase in market share compared to industry competitors; improvement of material and technical potential; improvement of human resources, etc.

\section{Conclusions}

The components of integrated tourism development strategies are considered, which include the following: the economic security strategy; financial strategy; investment strategy; innovative strategy; information strategy.

The factors that cause the need to create tourist clusters to ensure the sustainable development of entities of the tourism sector are identified, such as: instability of the national economy; features of the tourism sphere; the structure of participants in the tourism market; peculiarities of activity of small business entities.

According to the main components of economic security, the main factors that influence the implementation of the strategy of integrated development of the subjects of tourism are considered.

Table 7

The scale of levels of the strategy of integrated development of tourism sphere entities

\begin{tabular}{|c|l|}
\hline Levels of the strategy & \multicolumn{1}{c|}{ Characteristics of the strategy } \\
\hline High & $\begin{array}{l}\text { An analysis of the integrated development strategy of the tourism industry entity shows that the strategy is } \\
\text { formulated correctly, is effective, and ensures sustainable, rapid development. }\end{array}$ \\
\hline Average & $\begin{array}{l}\text { An analysis of the integrated development strategy of the tourism industry subject indicates that the strategy was } \\
\text { formulated incorrectly, is not effective enough, and provides little, slow development. }\end{array}$ \\
\hline Low & $\begin{array}{l}\text { An analysis of the integrated development strategy of the tourism industry entity indicates that the strategy was } \\
\text { formulated incorrectly, is inefficient, and does not support development at all. }\end{array}$ \\
\hline
\end{tabular}


This is because the main tool for ensuring the integrated development of the tourism industry is to improve the economic security of each participant in such an association. Thus, the following factors influence the implementation of the integrated development strategy: external (financial, informational, technical, technological, political, environmental) and internal (intellectual, personnel, motivational).

As a result of the study of the prerequisites for the formation of an integrated development strategy by creating a tourism cluster of small business entities, the following organizational recommendations for creating a cluster of tourism industry entities in the following areas are proposed: the type of integration structure, the number of participants, the consistency of interests of participants, distribution of responsibilities between participants.

The scheme of implementation of the strategy of integrated development of entities in the tourism sphere is offered, which consists of the following stages: analysis of conditions of cluster formation, definition of purpose and tasks of the cluster, identification of potential and interested participants of the cluster, assessment of the level of consistency of interests of cluster participants, definition of rules of functioning of the cluster, development and implementation of the cluster strategy, cluster performance assessment and monitoring.

\section{References:}

Ansoff, I., \& McDonnell, E. J. (1999). Novaya korporativnaya strategiya [The new corporate strategy]. St. Petersburg: PeterCom. (in Russian)

Kotler, P., \& Caslione, J. A. (2009). Khaotyka: upravlinnya ta marketynh $v$ epokhu turbulentnosti [Chaotics: The Business of Managing and Marketing in the Age of Turbulence]. Kyiv: Himgest, PLASKE. (in Ukrainian)

Gelter, H. (2017). Digital Tourism - An analysis of digital trends in tourism and customer digital mobile behavior for the Visit Arctic Europe project. Summary. Interreg Nord.

Potapiuk, I., Diachkov, D., \& Potapiuk, I. (2016). The peculiarities of special kinds of tourism in Ukraine. Mechanisms and models of development of entities tourist business: collective monograph / Ed. by A. Berezin, M. Bezpartochnyi. Riga: «Landmark-SIA ».

Overtourism: Understanding and Managing Urban Tourism Growth beyond. (2018). Madrid: UNWTO. 